\title{
Research on the Application of "Large Class Teaching and Small Class Discussion" Teaching Mode in Electronic Technology Courses Under the Background of the Development of Electronic Technology Field
}

\author{
Luya Zhang ${ }^{1, a}$, jisen Cheng ${ }^{2, b}$, and Jing Zhao ${ }^{3, c}$
}

\author{
${ }^{1}$ Experimental Training Base of School of Information and Communication, National University of Defense \\ Technology, Xi 'an, Shaanxi, China \\ ${ }^{2}$ PLA Unit 31401 Unit 153 Jinan Shandong China \\ ${ }^{3}$ Experimental Training Base of School of Information and Communication, National University of Defense \\ Technology, Xi 'an, Shaanxi, China

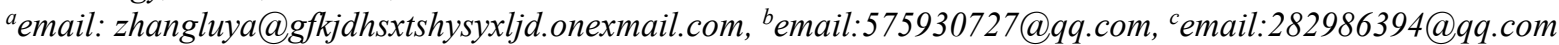

\begin{abstract}
Electronic technology course is the required professional basic course for engineering majors such as power electronic technology and electrical engineering in colleges and universities, which plays an important role in the training of electronic information professionals. Based on the latest development in the field of modern electronic technology as the background, this paper focuses on updating the teaching mode of the course on the basis of focusing on the development of electronic technology and updating the knowledge system and content, with the purpose of paying attention to the practical needs of students and improving their practical ability. Starting from the necessity of the teaching mode of "large class teaching and small class discussion", this paper discusses the implementation measures of this teaching mode, sorts out the key points and innovation points of this teaching mode, and summarizes the effects and problems of this teaching mode in electronic technology courses.
\end{abstract}

Keywords: Electronic Technology Course, large-scale class teaching, Small class discussion, practice of innovation.

\section{INTRODUCTION}

Whether the positioning of the beidou navigation system, navigation, two-way, information service, short message or embedded system and the popularity of the 5 $\mathrm{g}$ environment technology has become the conquest of new industries and new application of man-machine interactive system, electronic technology has been widely used in various fields, it also makes the from all walks of life to electronic technology put forward a higher level of professional and technical personnel at all levels. The electronic technology course is a required basic course for the electronic technology major in colleges and universities, which plays an important role in the training of electronic technology talents. On the basis of paying close attention to the development frontier of the industry and updating the knowledge system and content in time, the reform of teaching mode should not be ignored.

Several Opinions on Further Deepening Undergraduate Teaching Reform and Improving Teaching Quality in an All-round Way proposed by the Ministry of Education to break through the traditional teaching mode centered on knowledge imparting. In recent years, the teaching mode of "large class teaching and small class discussion" has become a research hotspot in the reform of education and teaching. Many local colleges and universities have organically combined "large class teaching + small class discussion" and formed many mature experience practices. However, many of the course teaching in the military non-commissioned officer vocational colleges are still stuck in the traditional large-class teaching mode, with poor teaching quality and effect, and it is difficult to 
achieve the purpose of educating people for war. How to use the mode of "large class teaching and small class discussion" to promote the curriculum teaching reform in an all-round way? these are questions that are worth studying.

\subsection{Research status at home and abroad}

Comenius, a Czech educator in the 17 th century, put forward the concept of "class teaching system" in his "Theory of Great Teaching", thus defining the basic outline of the theoretical basis of class teaching. In 1737, J.M. Gesner, a German scholar, introduced the teaching model of "small class discussion" into the university classroom for the first time. At the beginning of the 20th century, this teaching model was widely adopted in some famous universities in the United States. At present, this model has been integrated into the practice of higher education in the world. To become one of the most important teaching modes in first-class universities. Research shows that if the number of students in a small class is controlled to about 25 , the "coverage" of teachers' teaching is the best, which can effectively build an elite education system. However, domestic teaching resources are limited, so it is more difficult to achieve. Therefore, the teaching mode of "large class teaching, small class discussion" arises at the historic moment.In recent years, the teaching mode of "large class teaching and small class discussion" has been implemented by scholars represented by Peking University and other universities. Some scholars believe that the mode of small class discussion realizes the unity of teaching and discussion, strengthens students' consciousness of subject and cooperation, and cultivates students' innovation ability.

\subsection{Necessity of research}

First, although local colleges and universities have carried out the practical exploration of "small class discussion", the current academic circle has not reached a conclusion on how to carry out small class discussion specifically, and has not formed a mature paradigm for reference. Therefore, there is a broad space for research and discussion.

Second, the practice teaching of our college has been carried out for many years in the form of small class teaching group practice teaching training, has achieved better teaching effect. However, due to the limitation of teaching resources and conditions, the traditional instilling large class teaching mode is still adopted in the theoretical teaching, especially in the teaching classes with a large number of students, which is not conducive to the development of personality and the comprehensive ability of students is not easy to be improved.

Thirdly, due to the particularity of military academy education, special research or related researchers are urgently needed to analyze and practice this teaching mode, so as to provide valuable reference for the military education authorities.

Comprehensive analysis of domestic and foreign research literature, only some universities do the teaching with discussion ", "small class class especially in military academies and schools" small class discussion "on the one hand, the literature also is less, the army colleges and universities how to build up to the learners as the center" of "large class, small class discussion" the integration teaching mode, to education workers need to be further in-depth study. The research and practice of this teaching mode will provide reference for the curriculum reform and classroom teaching reform in colleges and universities, and also contribute to the innovative research of the teaching mode of vocational and technical education for sergeants.

\section{MAIN CONTENTS OF THE STUDY}

Following the principle of laying a solid foundation, paying attention to practice and improving skills, the research is carried out on the reform and implementation measures of the teaching mode of "large class teaching and small class discussion" of electronic technology courses, mainly involving two aspects:

\subsection{Theoretical foundation research of "large class teaching and small class discussion"}

Through consulting relevant literature, a deep understanding of "large class, small class discussion" Education background and requirements, at the same time the constructivism theory, bruner Education theory, Education philosophy guides based on the results (Outcome - -based Education, OBE) such as the theory of Education with time characteristic, principle and suitable for the sergeant electronic technology curriculum of vocational and technical Education goal, the combination of lay theoretical basis for the research.

\subsection{Teaching design and implementation of "large-class teaching and small-class discussion"}

Adopt online and offline mixed mode and project-driven;Small class discussion includes question-based discussion, flipped classroom, etc. The complete implementation plan of this mode is shown in Figure 1: 


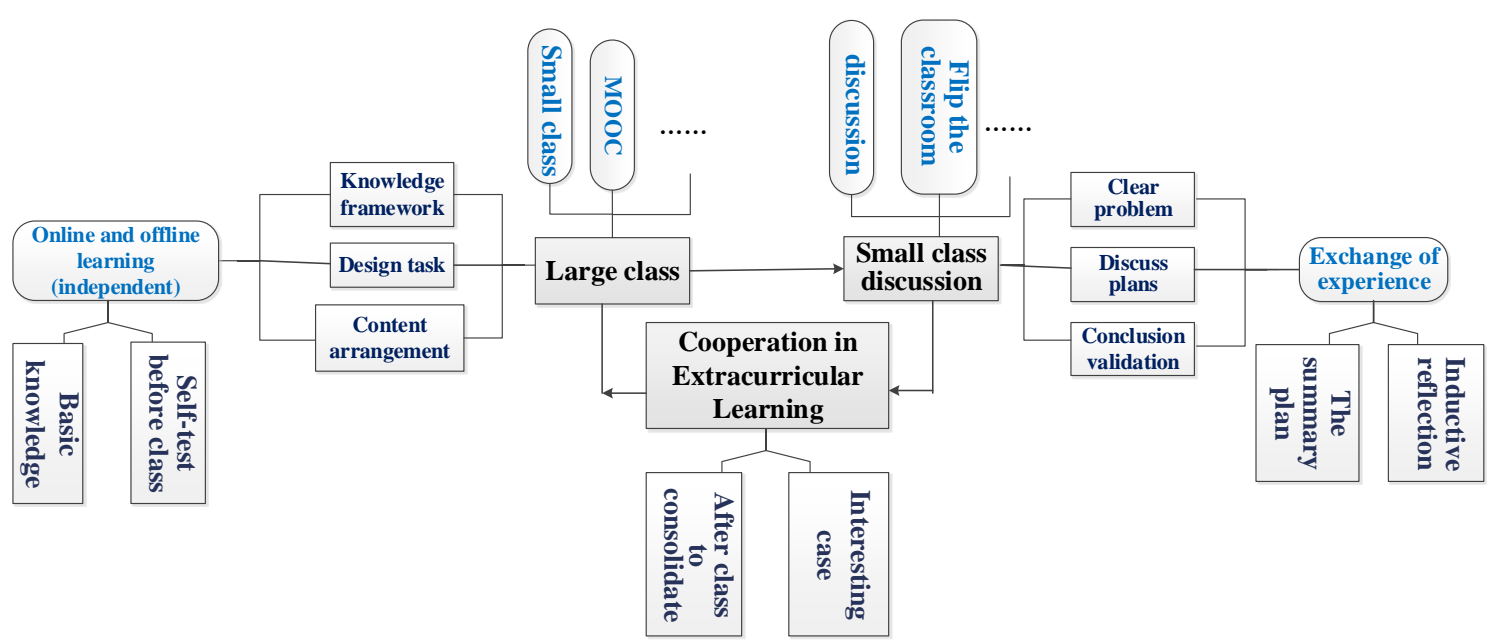

Fig. 1 Overall block diagram of the teaching mode of "large-class teaching and small-class discussion"

\subsubsection{Large class teaching (mixed online and offline teaching, etc.)}

The size of the large class is $45-60$ students for each large class, with concentrated teaching as the main implementation method, and knowledge system and important and difficult content explanation as the main line of the class. Students will conduct online self-learning (micro-course, MOOC, etc.) before class, and form diagnostic evaluation by self-testing before class, which will be summarized to the teaching instructor. In view of some common problems of students, improve the knowledge framework, grasp the key and difficult points, and sort out the main problems. The teaching is generally carried out in three steps: first, the formulation of course implementation plan, the conception of course design, the construction of knowledge framework, and the depth and breadth of key and difficult points; Second, the specific design of key teaching links, sorting out typical problems and cases, reasonable arrangement of the task of small class discussion; Third, teaching content arrangement, teaching time allocation, specific teaching, etc.

\subsubsection{Small class discussion (problem-based guidance, flipped classroom)}

There are about 20 people in a small class for discussion, and the students are divided into 3-4 groups with 5-7 people in each group, and equipped with an instructor. Small class seminars are arranged for 2 periods per chapter. The smart classroom, professional basic laboratory and other places are used for biweekly teaching to ensure adequate preparation time. Question-based guidance can be adopted, in which the teacher puts forward questions or teaching research projects in advance, and the students complete the relevant data collection, integration, discussion and determination of the plan and discussion before class, or the students can design the questions themselves and take the initiative to explore. In this process, the communication and cooperation between the students and others can be strengthened, and the prescribed tasks can be completed together. The teacher collected the design scheme of each group and commented on it, including process thinking analysis, experience and lesson summary, problem induction and reflection, etc.

\subsubsection{Cooperation in extracurricular learning}

Extracurricular cooperation mainly includes completing homework independently and collecting and discussing interesting cases. Through the arrangement of routine homework, the students can consolidate the knowledge they have learned in time, understand and master the common problem types and basic problem solving methods, so as to cultivate their independent thinking ability and lay a foundation for the application of knowledge points in the small class discussion.

The overall teaching mode is "large class teaching -small class discussion -- extracurricular learning cooperation", which integrates online learning before class and extracurricular learning and summary after class. A variety of teaching forms are combined to form a closed-loop teaching mode of timely feedback, which is mutually integrated and complementary, so as to achieve the unity of education efficiency and effect.

\subsubsection{Assessment and evaluation}

It breaks the simple assessment method of "the end examination decides everything", and makes a reasonable assessment of the effect of inquiry-based small-class discussion. The assessment results are also included in the course assessment scheme: the course assessment adopts the final theory examination $45 \%$, the stage practice examination $30 \%$, the usual homework $10 \%$, and the discussion class result $15 \%$. In the future, we can continue to follow up and optimize the assessment and evaluation method according to the course module allocation and course structure 
characteristics, and flexibly adjust the score proportion. Of exploratory of small class discussions achievements mainly include a small seminar participation, active degree, put forward the constructive and members of the cooperation, etc., such a complete profile of the individual and group combing quantitative scoring, diversification of diversified evaluation of the project, to encourage healthy competition between individual and group, to achieve "to the evaluation to promote teaching and to review construction".

\section{KEY AND DIFFICULT POINTS AND INNOVATION POINTS OF THE RESEARCH}

\subsection{Important and difficult points in teaching mode}

1. Study on the size, class classification standards, objectives and classroom teaching design of "small class discussion".

2. Build a diversified student achievement assessment system and optimize the proportion of various grades in the total evaluation.

\subsection{Innovation points of teaching model}

1. Integrate online and offline learning, extracurricular learning and communication into the process of "large-class teaching and small-class discussion", integrate the advantages of various teaching modes to form a complete, real-time feedback and processing teaching process, and put forward a new idea of teaching design.

2. With the help of micro-class, MOOC and other current teaching reform results, part of the teaching content, the use of information, network and open teaching advantages, expand the students' knowledge vision, so that sometimes learning is no longer limited by time and space, provides a strong guarantee for the development of small class discussion.

3. Closed-loop teaching mode makes teaching content, teaching mode, assessment and evaluation methods and summary of teaching methods effectively connected, reflecting that teaching benefits teaching.

\section{RESEARCH VALUE}

1. Research on the teaching mode of "large-class teaching and small-class discussion" can provide some reference for the reform of teaching mode of basic courses of vocational and technical education for non-commissioned officers.

2. This teaching mode is conducive to equal communication and two-way communication between teachers and students, shorten the distance between teachers and students, and form a democratic and harmonious new teacher-student relationship.

3. By teaching knowledge framework and subject theory knowledge in large classes, supplemented by discussion cases, discussion and question-answering in small classes, the purpose of optimizing teaching resources and improving teaching quality can be realized, adding new force to promote the reform and innovation of electronic technology courses.

\section{CONCLUSION}

Through the theoretical research and analysis of the teaching mode of "large class teaching and small class discussion", this paper points out the necessity of the research of this teaching mode, puts forward the concrete implementation measures under this teaching mode, and summarizes the key points and innovation points. Were also found in the implementation of class, students for a small seminar of recognition is higher, the teaching way makes the students' ability of using knowledge to solve the problem is greatly increased, make the students in the discussion of a variety of angles to deepen the understanding of knowledge, but students' independent speech situation is lacking, participation to improve, to strengthening the ability of independent thinking, evaluation methods are to be further optimized.

\section{REFERENCES}

[1] Zhu,H,Ma,L.P,Xiong,Y. (2016) Research on the effect of teaching mode of "large class teaching and small class discussion" $[\mathrm{J}]$. Higher Education Studies in China, (1): 42-47.

[2] Qin,S,Zhang,Z.F,Jiao,Z.H. (2019) Exploration on the mode of "large class teaching + small class discussion" in university public courses[J]. Journal of Hangzhou Dianzi University (Social Science Edition), 15(1): 65-69.

[3] Zhang,X,H. (2003) Small class teaching and its reflection[J]. Curriculum and teaching, (9): 589593.

[4] Liu,X.J. (2017) Reform of teaching mode of "large class teaching + small class discussion" $[\mathrm{J}]$. University Education in China, (2): 19-24.

[5] Yao,L.M,Zhu,L.M,Yang,J. On the enlargement of class size in colleges and universities[J]. Higher Education Studies in China, (6): 68-72.

[6] Joseph,J. L. (2009) Size matters : an exploratory comparison of smalland large-class university lecture introductions[J]. English for Specific Purposes, (28) : 42-57. 